\title{
ANALISIS PERUBAHAN SUHU DAN TEKANAN UDARA PERMUKAAN TERHADAP PERTUMBUHAN AWAN CUMULONIMBUS (Cb) di BANDAR UDARA (BANDARA) SULTAN SYARIF KASIM II PEKANBARU
}

\author{
Krispina Br Damanik, Yulia Fitri, Sanya Gautami \\ Mahasiswa Jurusan Fisika, Email:krispina_damanik@yahoo.com \\ Dosen Jurusan Fisika, Email: yulia_fitri18@yahoo.com \\ Dosen Jurusan Fisika, Email: nyamet40@gmail.com \\ Universitas Muhammadiyah Riau \\ J1. KH. Ahmad Dahlan No.88, Sukajadi Pekanbaru-28124 \\ Telp. (0761) 35008, 20497 Fax (0761) 36912
}

\begin{abstract}
The formation of the Cumulonimbus ( $\mathrm{Cb}$ ) cloud is very important to be analyzed, because it may cause weather changes which is very dangerous for flight activities. This research will analyze the formation of the $\mathrm{Cb}$ at Pekanbaru. The data about air temperature and pressure taken on October-December 2012 at Sultan Syarif Kasim II Airport, Pekanbaru. The analysis about the formation of $\mathrm{Cb}$ needed to help the focecaster to give information or suggestion about the Cb formatting. The information showed that there is temperature and pressure changes which is inversely proporsional. When the temperature up, the pressure down. This analysis said that the Cb formation on October - December 2012, $79 \%$ tended to be started with cumulus cloud. On October, there is temperature ascension from $07.00 \mathrm{am}$ to $02.00 \mathrm{pm}$ about $7,5^{\circ} \mathrm{C}$ and the pressure decrease from 10.00 am to $04.00 \mathrm{pm}$ is about $4,5 \mathrm{mb}$ with $12,5 \% \mathrm{Cb}$ formation. On November, there is temperature ascension about 7,6 ${ }^{\circ} \mathrm{C}$ from 07.00 am to $02.00 \mathrm{pm}$. The pressure decreased about 4,6 $\mathrm{mb}$ at 10.00 am to $04.00 \mathrm{pm}$ with $16,3 \%$ Cb formation. On December, from 07.00 am to $02.00 \mathrm{pm}$, the temperature ascends about $7,1^{\circ} \mathrm{C}$ and the pressure decreases about $4,1 \mathrm{mb}$ with $11,9 \% \mathrm{Cb}$ formation. The analysis showed the higher temperature, the lower pressure make the Cb formation is bigger.
\end{abstract}

Keywords: Cumulonimbus,temperature, pressure

\section{PENDAHULUAN}

Pesatnya penerbangan jarak pendek antara pulau di Indonesia dan penerbangan jarak jauh di dunia, menjadi tantangan bagi badan meteorologi klimatologi geofisika (BMKG). Hal ini khususnya bagi para prakirawan (forecaster) yang bertugas di bandara. Dimana, Prakirawan bertugas untuk memberikan pelayanan penerbangan lebih cepat, akurat dan sekaligus mampu memberikan peringatan dini untuk keselamatan penerbangan.

Mobilitas masyarakat kota Pekanbaru semakin tinggi seperti saat ini, yang dapat terlihat dari semakin tingginya jadwal penerbangan di Bandar udara (bandara) Sultan Syarif Kasim (SSK) II Pekanbaru. Hal ini menjadikan prakiraan cuaca harian sangat dibutuhkan, karena dengan memperhatikan prakiraan cuaca tersebut maskapai penerbangan dapat menyesuaikan rencana dalam menggunakan jasa angkutan udara. Informasi cuaca mempunyai peranan penting sebagai bahan pertimbangan bagi pembuat keputusan baik sebelum maupun sewaktu penerbangan. Oleh karena itu, prakiraan cuaca dijadikan pedoman pokok baik dalam perencanaan maupun pelaksanaan penerbangan dengan harapan lancar tanpa gangguan cuaca buruk.

Menurut Yamaka pada tahun 1998, wilayah Indonesia disebut sebagai benua bahari. Wilayah ini di sekitar khatulistiwa dengan penerimaan radiasi matahari sepanjang tahun. Wilayah Indonesia juga disebut sebagai wilayah perairan terpanas di dunia dan sebagai wilayah terpenting dalam sistem klimatologi global. Kondisi wilayah tersebut mengakibatkan aktivitas awan konvektif mudah terjadi.

Salah satu kondisi cuaca yang sangat berbahaya dalam penerbangan ialah munculnya awan cumulonimbus $(\mathrm{Cb})$. Awan jenis ini sangat berbahaya dan ganas, karena di dalam awan ini terdapat hujan deras, petir, badai atau batu es 
(hailtones). Selain itu pesawat yang terbang di bawah awan $\mathrm{Cb}$ dapat diangkat masuk kedalam awan sehingga pilot mendapat kesulitan untuk mengendalikan pesawatnya. Awan jenis cumulus terutama awan $\mathrm{Cb}$ disebut jalur maut bagi dunia penerbangan dan harus dihindari. Awan Cumulus adalah Awan dengan pertumbuhan pertikal dan berbentuk kapuk putih yang melayang di udara dan berkelompok kelompok sendiri. Awan $\mathrm{Cb}$ dapat terjadi jika salah satu dari beberapa kondisi berikut terpenuhi diantaranya yaitu ada pemanasan sangat intensif oleh matahari pada udara lembab dipermukaan seperti daerah pertemuan angin (konvergen), daerah belokan angin yang tajam (trough), dan lain-lain.

Penelitian ini dilakukan untuk menganalisa perubahan suhu dan tekanan udara permukaan harian sebagai indikasi terhadap pertumbuhan awan $\mathrm{Cb}$ di Bandara SSK II Pekanbaru. Perubahan pola suhu dan tekanan udara ini dianalisa untuk menemukan trend munculnya awan $\mathrm{Cb}$ di bandara SSK II Pekanbaru.

\section{METODOLOGI PENELITIAN}

\section{Lokasi dan Waktu Penelitian}

Penelitian ini dilaksanakan di stasiun Meteorologi Bandara SSK II Pekanbaru dengan menggunakan data bulan Oktober sampai Desember tahun 2012. Waktu penelitian dimulai dari bulan januari 2013 sampai januari 2014.

\section{Desain Penelitian}

\begin{tabular}{|c|}
\hline Pengumpulan \\
dan \\
Pencatatan \\
Data Sulu \\
(T) dan \\
Tekanan(P) \\
bulan \\
rutmox - \\
\hline
\end{tabular}

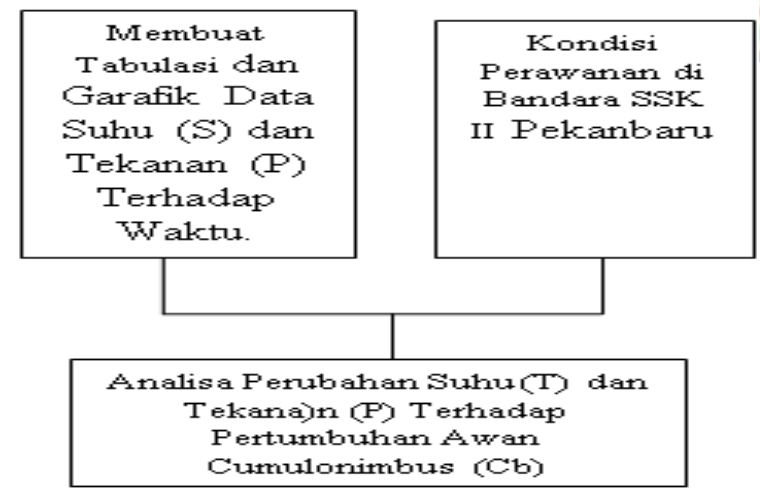

Gambar 1. Diagram penelitian
Dengan melihat grafik pergerakan suhu dan tekanan udara permukaan terhadap waktu diharapkan akan diperoleh suatu trend grafik harian yang dapat digunakan untuk probabilitas tumbuhnya awan $\mathrm{Cb}$ di Bandara SSK II Pekanbaru.

\section{HASIL DAN PEMBAHASAN Pertumbuhan Awan $\mathrm{Cb}$ pada bulan Oktober 2012}

Hasil pengambilan dan pengelolaan data suhu dan tekanan udara di Stasiun Meteorologi SSK II Pekanbaru pada bulan Oktober Desember 2012 menghasilkan 131 data kejadian awan $\mathrm{Cb}$. Gambar perubahan suhu udara terhadap pertumbuhan awan $\mathrm{Cb}$ pada bulan Oktober tahun 2012 di Stasiun Meteorologi SSK II Pekanbaru dapat dilihat pada Gambar 1.

Suhu rata - rata maksimum terjadi pada bulan ini adalah $31,5^{\circ} \mathrm{C}$ dan suhu minimun rata - rata terjadi pada bulan ini adalah $23,9{ }^{\circ} \mathrm{C}$. Suhu udara permukaan mengalami peningkatan pada pukul 07.00 WIB hingga pukul 14.00 WIB dengan nilai kenaikan sekitar $7,5{ }^{\circ} \mathrm{C}$ dan mengalami penurunan mulai pukul $14.00 \mathrm{WIB}$ hingga pukul 06.00 WIB dengan penurunan sekitar $7,8{ }^{\circ} \mathrm{C}$.

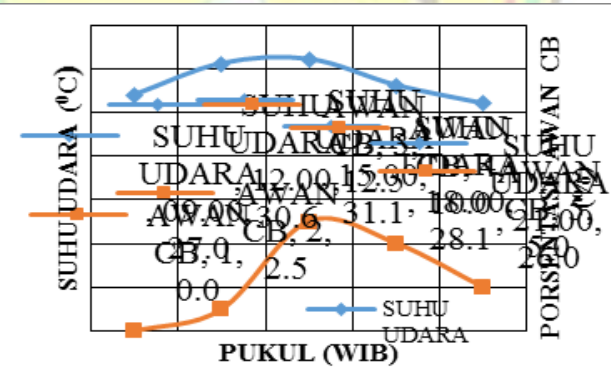

Gambar 2. Perubahan suhu udara permukaan terhadap pertumbuhan Awan Cb bulan Oktober 2012

Perubahan tekanan udara rata - rata dapat dilihat pada Gambar 2. Tekanan maksimum rata - rata terjadi pada bulan ini adalah dengan nilai $1010,0 \mathrm{mb}$ dan tekanan minimun rata - rata terjadi pada bulan ini adalah dengan nilai 1005,5 mb. Tekanan udara mengalami peningkatan pada pukul 07.00 WIB hingga pukul 10.00 WIB dengan nilai kenaikan sebesar $1,2 \mathrm{mb}$. Semakin meningkatnya proses pemanasan akibat radiasi 
sinar matahari, menyebabkan terjadinya proses mekanik aliran udara sehingga tekanan udara menurun dengan nilai sekitar $4,5 \mathrm{mb}$ pada pukul 10.00 WIB sampai pukul 16.00 WIB. Pada pukul 16.00 WIB hingga pukul 23.00 WIB tekanan udara rata - rata mengalami kenaikan seiring dengan berkurangnya intensitas penyinaran matahari dengan nilai lebih kurang sebesar $3.7 \mathrm{mb}$. Tekanan udara mengalami penurunan kembali pada pukul 23.00 WIB hingga pukul 04.00 WIB dengan nilai sekitar 1,6 mb. Nilai penurunan tekanan lebih kecil dibandingkan dengan nilai penurunan tekanan udara pada saat pemanasan oleh matahari karena belum adanya proses konveksi yang cukup besar dan aliran udara yang cenderung calm.

Peningkatan suhu udara permukaan mengindikasikan bahwa telah terjadi proses pemanasan (konveksi) yang telah memicu pengangkatan massa udara akibat proses konvektif yang ditandai dengan munculnya awan cumulus. Pertumbuhan awan pada bulan ini dapat dilihat pada tabel pertumbuhan awan di lampiran VII. Persentase pertumbuhan awan cumulus pada pukul 08.00 WIB - 12.00 WIB dibulan ini mencapai $76 \%$ yang ditandai dengan sandi 1,2 dan 8 (lampiran VII). Kejadian awan $\mathrm{Cb}$ cenderung terjadi setelah adanya pertumbuhan awan cumulus.

Kejadian awan $\mathrm{Cb}$ pada bulan ini lebih banyak terjadi pada sore dan malam hari yaitu pada pukul 15.00 WIB sampai pukul 19.00 WIB. Persentase kejadian awan $\mathrm{Cb}$ dengan sandi 3 dan 9 (lampiran VII) terbanyak terjadi pada pukul 15.00 WIB dengan nilai $12,5 \%$ pada saat suhu udara $31,1{ }^{\circ} \mathrm{C}$ dan tekanan udara 1005,7 mb.

Pada tanggal 12 Oktober 2012, awan Cb yang terjadi memiliki durasi yang cukup lama yaitu selama 14 jam mulai pukul 17.00 WIB sampai pukul 06.00 WIB. Peningkatan suhu udara permukaan yang terjadi pada pukul 07.00 WIB sampai pukul $14.00 \mathrm{WIB}$ sebesar $8,9^{\circ} \mathrm{C}$, dimana berada diatas nilai rata-rata suhu permukaan pada bulan Oktober 2012. Sehingga hal ini kemungkinan yang menyebabkan munculnya awan $\mathrm{Cb}$ dalam jangka waktu yang lama. Jika dianalisa pada pertumbuhan awan cumulus pada tanggal 12 Oktober 2012 mulai pukul 11.00 WIB hingga pukul 16.00 WIB telah terjadi awan Cumulus, dan pukul 17.00 WIB hingga pukul 06.00 WIB adanay kejadian awan $\mathrm{Cb}$.

Hal ini juga dapat dilihat dari data tekanan pada tanggal 12 Oktober 2012 terjadi peningkatan tekanan udara pada pukul 07.00 WIB sampai pukul 10.00 WIB sebesar $1,3 \mathrm{mb}$ serta mengalami penurunan tekanan udara pukul 10.00 WIB sampai pukul 16.00 WIB sebesar 5,3 mb. Nilai perubahan tekanan udara pada hari ini juga berada di atas nilai rata-rata tekanan udara pada bulan Oktober, sehingga hal ini dapat memicu pertumbuhan awan yang cukup intens.

Hasil analisis streamline (pola angin lapisan 3000 feet) menunjukkan adanya pola angin konvergensi (daerah pertemuan angin) di atas wilayah Riau seperti pada Gambar 3. Pola angin konvergensi merupakan pola angin yang sangat mendukung terjadinya pertumbuhan awan karena pola angin ini menyebabkan uap air menumpuk di atas wilayah terjadinya konvergensi. Selain itu curah hujan yang tercatat pada tanggal 12 Oktober 2012 sebesar 46,2 mm, yang merupakan curah hujan tertinggi pada bulan ini.

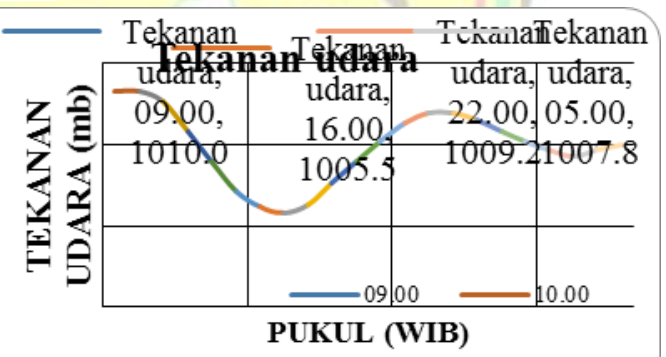

Gambar 3. Perubahan tekanan udara permukaan terhadap pertumbuhan Awan Cb bulan Oktober 2012

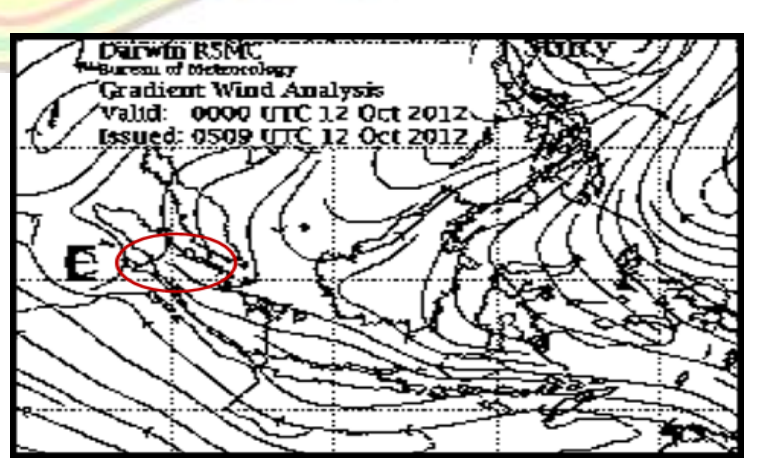

Gambar 4. Pola angin 3000 feet pada tanggal 12 Oktober 2012 


\section{Pertumbuhan Awan Cb pada bulan Nopember 2012}

Gambar perubahan suhu udara terhadap pertumbuhan awan $\mathrm{Cb}$ pada bulan Oktober tahun 2012 di Stasiun Meteorologi SSK II Pekanbaru dapat dilihat pada gambar 4:

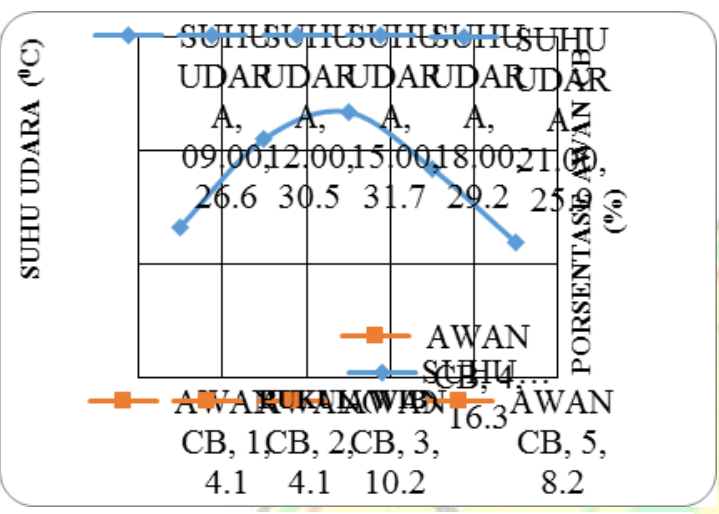

Gambar 5. Perubahan suhu udara permukaan terhadap pertumbuhan Awan Cb bulan Nopember 2012

Suhu maksimum rata - rata terjadi pada bulan ini adalah $31,8{ }^{\circ} \mathrm{C}$ dan suhu minimum rata - rata adalah $23,9{ }^{\circ} \mathrm{C}$. Suhu udara permukaan mengalami peningkatan suhu udara permukaan pada pukul 07.00 WIB hingga 14.00 WIB dengan nilai kenaikan sekitar $7,6{ }^{\circ} \mathrm{C}$, dan mengalami penurunan suhu udara mulai pukul 15.00 WIB hingga pukul 06.00 WIB dengan nilai penurunan sekitar $7,9^{\circ} \mathrm{C}$.

Perubahan tekanan udara rata-rata pada bulan Nopember tahun 2012 dapat dilihat pada Gambar 5. Tekanan rata - rata maksimum terjadi pada bulan ini adalah 1009,5 mb dan tekanan minimun rata - rata terjadi pada bulan ini adalah $1004,9 \mathrm{mb}$. Tekanan udara mengalami peningkatan pada pukul 07.00 WIB hingga pukul 10.00 WIB dengan nilai kenaikan lebih kurang sebesar 1,1 mb, dan mengalami penurunan pada pukul 10.00 WIB hingga pukul 16.00 WIB dengan nilai sekitar 4,6 mb Pada pukul 16.00 WIB hingga pukul 23.00 WIB tekanan udara rata-rata harian kembali menunjukkan peningkatan dengan nilai lebih kurang sebesar $4.3 \mathrm{mb}$, dan selanjutnya tekanan rata - rata mengalami penurunan kembali pada pukul 23.00 WIB sampai dengan pukul 04.00 WIB dengan nilai $2 \mathrm{mb}$.

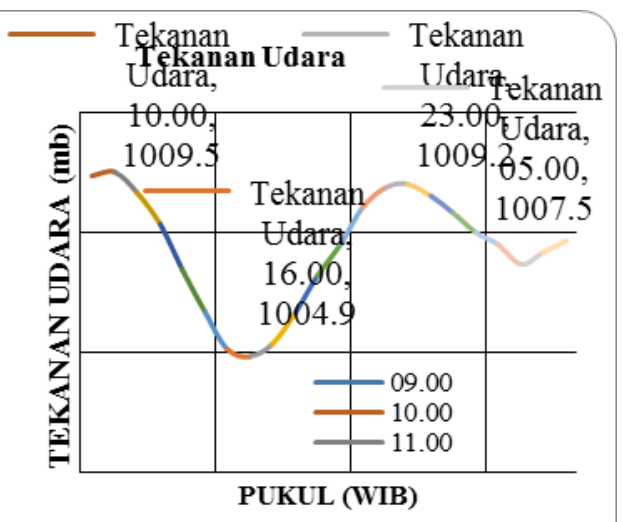

Gambar 6. Perubahan tekanan udara permukaan terhadap pertumbuhan Awan Cb bulan Nopember 2012

Pertumbuhan awan pada bulan Nopember 2012 dapat dilihat pada tabel pertumbuhan awan dilampiran VIII. Persentase pertumbuhan awan cumulus pada pukul 08.00 WIB - 12.00 WIB dibulan ini mencapai $89 \%$ yang ditandai munculnya awan cumulus dengan sandi 1,2 dan 8 (dilampiran VIII). Kejadian awan $\mathrm{Cb}$ yang terjadi pada bulan ini lebih banyak terjadi pada sore dan malam hari yaitu pada pukul 15.00 WIB sampai pukul 19.00 WIB. Persentase kejadian awan $\mathrm{Cb}$ terbanyak terjadi pada pukul 18.00 WIB dengan nilai $16,3 \%$ pada saat suhu $29,2{ }^{\circ} \mathrm{C}$ dan tekanan udara $1006,0 \mathrm{mb}$.

Pada tanggal 25 Nopember 2012, awan $\mathrm{Cb}$ yang terjadi memiliki durasi yang cukup lama yaitu selama 10 jam mulai pukul 14.00 WIB sampai pukul 23.00 WIB. Peningkatan suhu udara pada tanggal 25 Nopember 2012 yang terjadi pada pukul 07.00 WIB sampai pukul 14.00 WIB sebesar $8.1^{\circ} \mathrm{C}$, dimana berada diatas nilai rata-rata suhu udara permukaan pada bulan Nopember 2012 dan mengalami penurunan mulai pukul 14.00 WIB hingga pukul 06.00 WIB. Sehingga hal inilah yang menyebabkan munculnya awan $\mathrm{Cb}$ yang lama. Pada kejadian awan $\mathrm{Cb}$ selalu diawali dengan pertumbuhan awan cumulus.

Jika dilihat dari perubahan tekanan udara pada tanggal 25 Nopember, tekanan udara mengalami kenaikan pada pukul 07.00 WIB sampai pukul 10.00 WIB sebesar $1.9 \mathrm{mb}$, serta mengalami penurunan tekanan udara pukul 10.00 WIB sampai pukul 16.00 WIB sebesar 4,2 
mb. Selain itu, analisis streamline menunjukkan adanya pola pusaran angin tertutup (sirkulasi Eddy) di atas wilayah Riau dapat dilihat pada Gambar 6. Pusaran angin tertutup ini merupakan gangguan cuaca yang dapat mendukung terjadinya pertumbuhan awan karena pola angin ini juga dapat menyebabkan uap air menumpuk di atas wilayah terjadinya gangguan.

Selain pada tanggal 25 Nopember 2012, tanggal 26 Nopember 2012 juga terjadi awan $\mathrm{Cb}$ yang terjadi memiliki durasi cukup lama, mencapai 13 jam mulai pukul 12.00 WIB sampai pukul 03.00 WIB namun durasi kejadian awan $\mathrm{Cb}$ pada pada hari ini memiliki jeda 1-2 jam hingga pembentukan awan $\mathrm{Cb}$ yang baru. Hal ini menunjukkan banyaknya kandungan uap air yang terdapat pada tanggal 26 Nopember 2012 yang menyebabkan awan $\mathrm{Cb}$ mudah terbentuk.

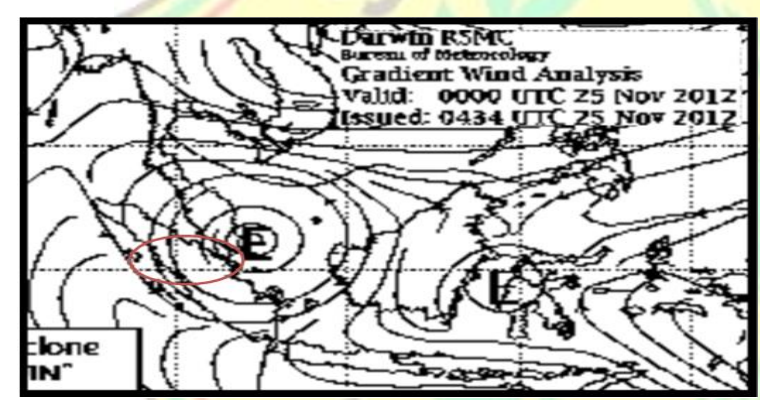

Gambar 7. Pola angin 3000 feet pada tanggal 25 Nopember 2012

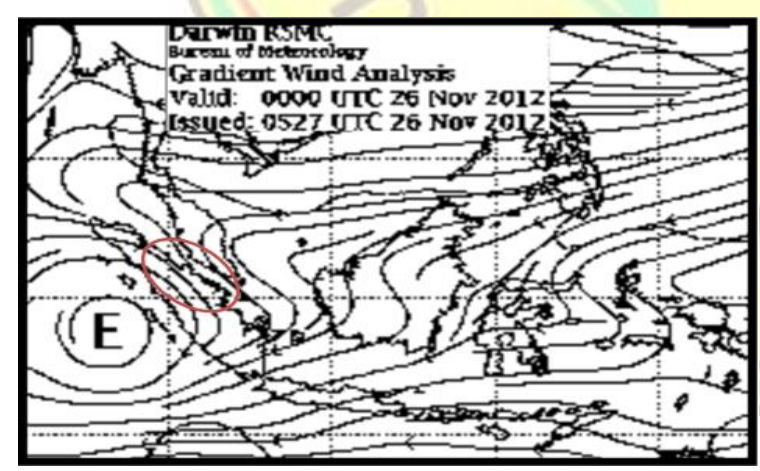

Gambar 8. Pola angin 3000 feet pada tanggal 26 Nopember 2012

Untuk peningkatan suhu udara pada tanggal 26 Nopember 2012 yang terjadi pada pukul 07.00 WIB sampai pukul 14.00 WIB sebesar $8,0^{\circ} \mathrm{C}$ dan mengalami penurunan mulai pukul 14.00 WIB hingga pukul 06.00 WIB. Kejadian awan $\mathrm{Cb}$ pada tanggal 26 Nopember 2012 juga diawali dengan pertumbuhan awan cumulus.

Jika dilihat dari perubahan tekanan pada tanggal 26 Nopember 2012, dimana nilai peningkatan tekanan udara pada pukul 07.00 WIB sampai pukul 10.00 WIB berada di atas nilai rata-rata hariannya Namun untuk penurunan tekanan udara pukul 10.00 WIB sampai pukul 16.00 WIB nilainya $0.4 \mathrm{mb}$ di bawah nilai rata-rata hariannya.

Selain itu, pada tanggal 26 Nopember 2012 juga terdapat pola angin konvergensi di atas wilayah Riau (Gambar 8), kondisi ini turut mendukung pertumbuhan awan $\mathrm{Cb}$ yang cukup intens. Untuk tanggal 26 Nopember 2012, perubahan tekanan udara yang terjadi pada pukul 07.00 WIB sampai pukul 10.00 WIB yaitu mengalami peningkatan sebesar $1.7 \mathrm{mb}$, serta penurunan tekanan udara pukul 10.00 WIB sampai pukul 16.00 WIB sebesar $5,4 \mathrm{mb}$. Nilai perubahan tekanan udara pada tanggal 12 Oktober 2012 juga berada di atas nilai rata-rata hariannya.

Selain itu Curah hujan yang tercatat pada tanggal 25 Nopember 2012 sebesar 1,5 mm dan pada tanggal 26 Nopember 2012 sebesar 18,9 $\mathrm{mm}$ dan cuaca yang tercatat sudah terjadi. Tanggal 25 dan 26 Nopember 2012, awan $\mathrm{Cb}$ yang terjadi cukup signifikan.

\section{Pertumbuhan Awan $\mathrm{Cb}$ pada bulan Desember 2012 \\ Perubahan Suhu Udara terhadap} pertumbuhan Awan $\mathrm{Cb}$ pada bulan Desember tahun 2012 di Stasiun Meteorologi SSK II Pekanbaru dapat dilihat pada gambar 8. Dari grafik 4.8 menunjukkan bahwa selama bulan Desember pada tahun 2012 di Stasiun Meteorologi SSK II Pekanbaru, suhu udara rata - rata maksimum pada bulan ini adalah sekitar $30,7^{\circ} \mathrm{C}$ dan suhu minimum pada bulan ini adalah $23,9^{\circ} \mathrm{C}$. Suhu udara permukaan mengalami peningkatan pada pukul 07.00 WIB sampai 14.00 WIB dengan nilai kenaikan sebesar 7, $0^{\circ} \mathrm{C}$ dan mengalami penurunan pada pukul 14.00 WIB hingga pukul 06.00 WIB dengan nilai penurunan sekitar $7,1{ }^{\circ} \mathrm{C}$. 
Pola perubahan tekanan udara rata-rata pada bulan Desember 2012 dapat dilihat pada Gambar 9. Tekanan udara rata - rata maksimum terjadi pada bulan ini adalah sekitar 1009,1 mb dan tekanan udara minimun rata - rata adalah sekitar 1005,0 mb.

Pola perubahan tekanan udara yang terjadi sama dengan bulan Oktober dan Nopember 2012 yaitu mengalami peningkatan pada pukul 07.00 WIB hingga pukul 10.00 WIB dengan nilai kenaikan lebih kurang sebesar 1,1 mb. Tekanan udara di Stasiun Meteorologi tercatat mengalami penurunan pada pukul 10.00 WIB hingga pukul 16.00 WIB, tekanan udara rata - rata tersebut menurun dengan nilai lebih kurang sebesar 4,1 mb. Kemudian pada pukul 16.00 WIB hingga pukul 22.00 WIB tekanan udara meningkat dengan nilai kenaikan lebih kurang sebesar 3.9 mb. Selanjutnya, tekanan rata - rata mengalami penurunan kembali pada pukul 22.00 WIB hingga pukul 04.00 WIB dengan nilai lebih kurang $1,9 \mathrm{mb}$.

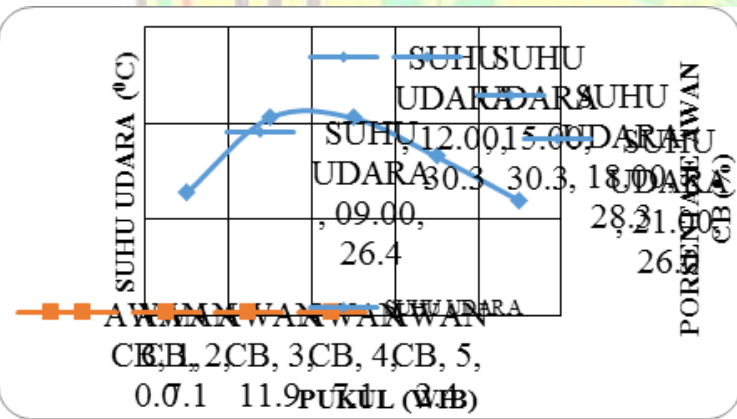

Gambar 9. Perubahan suhu udara permukaan terhadap pertumbuhan Awan Cb bulan Desember 2012

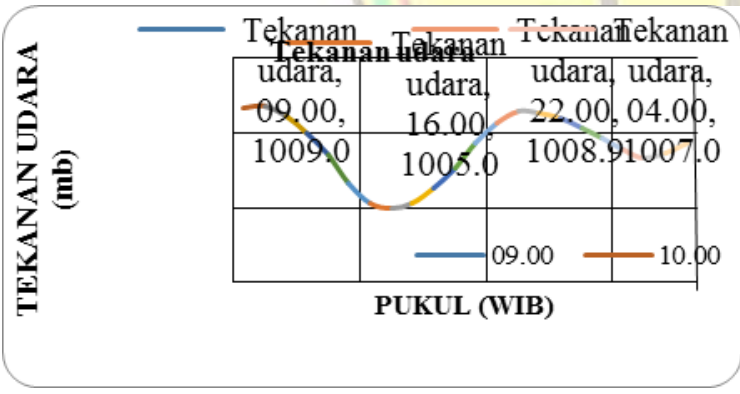

Gambar 10. Perubahan Tekanan udara permukaan terhadap pertumbuhan Awan Cb bulan Desember 2012

Peningkatan suhu udara permukaan mengindikasikan bahwa telah terjadi proses pemanasan (konveksi) yang telah memicu pengangkatan massa udara akibat proses konvektif yang ditandai dengan munculnya awan cumulus. Pertumbuhan awan pada bulan ini dapat dilihat pada tabel pertumbuhan awan dilampiran IX. Persentase pertumbuhan awan cumulus pada pukul 08.00 WIB - 12.00 WIB dibulan ini mencapai $72 \%$. Dimana nilai ini menunjukkan telah terjadi pengangkatan massa udara akibat proses konvektif yang ditandai dengan tumbuhnya awan cumulus dengan sandi 1,2 dan 8 (dilampiran IX).

Kejadian awan $\mathrm{Cb}$ banyak terjadi pada sore dan malam hari yaitu pada pukul 15.00 WIB sampai 19.00 WIB. Persentase kejadian awan $\mathrm{Cb}$ terbanyak terjadi pada pukul 15.00 WIB dengan nilai $11,90 \%$ pada saat suhu $30,2^{\circ} \mathrm{C}$ dan tekanan 1005,2 mb. Setelah kejadian awan $\mathrm{Cb}$, dilanjut dengan masa punah yang ditandai dengan adanya awan Stratocumulus (sandi 4 dan 5) dilampiran IX.

Pada bulan Desember 2012, kejadian awan $\mathrm{Cb}$ yang cukup signifikan terjadi pada tanggal 1 dan 12 Desember 2012. Untuk tanggal 1 Desember 2012 perubahan suhu udara yang terjadi pada pukul 07.00 WIB sampai pukul 13.00 WIB sebesar $7,6{ }^{\circ} \mathrm{C}$ dan terdapat diatas nilai rata-rata pada bulan Desember 2012. Pada tanggal 1 Desember 2012 kejadian awan cb diawali dengan pertumbuhan awan cumulus mulai pukul 10.00 WIB hingga pukul 16.00 WIB.

Jika dilihat dari perubahan tekanan udara pada saat kejadian awan $\mathrm{Cb}$, dimana nilai ratarata dari kenaikan dan penurunan tekanan udara yang tercatat memiliki nilai diatas nilai rata-rata bulan ini yaitu mengalami peningkatan sebesar $2.1 \mathrm{mb}$ pada pukul 07.00 WIB sampai pukul 09.00 WIB, serta penurunan tekanan udara pukul 09.00 WIB sampai pukul 17.00 WIB sebesar $4.6 \mathrm{mb}$.

Dari hasil analisis streamline pada Gambar 4.10 menunjukan adanya kondisi atmosfer yang hampir sama dengan tanggal 12 Oktober 2012, yaitu adanya pola angin konvergensi yang mendukung pertumbuhan awan yang cukup intens karena mengandung banyak uap air. Awan cb yang terjadi pada tanggal 1 Desember 
2012 memiliki durasi selama 8 jam mulai pukul 17.00 WIB hingga pukul 24.00 WIB.

Selain itu pada tanggal 12 Desember 2012, durasi awan $\mathrm{Cb}$ yang terbentuk juga signifikan yaitu mulai pukul 17.00 WIB hingga pukul 04.00 WIB dengan jeda pada pukul 18.00 WIB dan 20.00 WIB. Kondisi perubahan suhu udara pada pukul 07.00 WIB sampai pukul 12.00 WIB sebesar $8.3{ }^{\circ} \mathrm{C}$. Parameter suhu udara pada tanggal 12 Desember 2012 ini juga memiliki nilai diatas rata-rata pada bulan Desember 2012. Kejadian awan $\mathrm{Cb}$ pada tanggal 12 Desember 2012 juga diawali dengan pertumbuhana awan cumulus.

Untuk tanggal 12 Desember 2012, jika dilihat dari perubahan tekanan udara yang terjadi pada pukul 07.00 WIB sampai pukul 10.00 WIB yaitu mengalami peningkatan sebesar $0.9 \mathrm{mb}$, nilai ini berada di bawah rata-rata nilai bulan ini yaitu $1.1 \mathrm{mb}$. Kemudian tekanan udara mengalami penurunan tekanan udara pukul 10.00 WIB sampai pukul 16.00 WIB sebesar 4.5 $\mathrm{mb}$, nilai perubahan tekanan udara pada rentang waktu ini berada di atas nilai rata-rata hariannya

Hasil analisis streamline (pola angin lapisan 3000 feet) menunjukkan adanya pola angin shearline (belokan angin). Pola angin shearline secara teori juga mendukung pertumbuhan awan hujan, karena pada saat terjadi pola shearline, kecepatan angin cenderung lebih melambat. Melambatnya pergerakan angin menyebabkan massa udara menumpuk dilokasi terjadinya pola angin shearline, dengan pemanasan yang cukup tinggi dan didukung oleh ketersedian uap air yang cukup banyak maka pertumbuhan awan $\mathrm{Cb}$ yang terjadi cukup intens. Selain itu curah hujan yang tercatat pada tanggal 1 Desember 2012 sebesar 4,5 $\mathrm{mm}$ dan pada tanggal 12 Desember 2012 sebesar 21,6 mm dan cuaca yang tercatat sudah terjadi RA dan TSRA.

Dari pembahasan perubahan tekanan udara pada bulan Oktober hingga Desember 2012 bersesuaian dengan perubahan suhu udara rata rata dan pertumbuhan awan $\mathrm{Cb}$. Dimana, bila suhu udara mengalami peningkatan, tekanan udara mengalami penurunan maka dapat menyebabkan adanya massa udara yang naik dan dapat mendukung terjadinya pertumbuhan awan. Dengan kenaikan suhu udara pada pukul 07.00 WIB sampai pukul 12.00 WIB sebesar lebih kurang sebesar $6,4^{\circ} \mathrm{C}$ dan kenaikan tekanan udara pada pukul 07.00 WIB sampai pukul 10.00 WIB lebih kurang sebesar $1,1 \mathrm{mb}$ telah terjadi pertumbuhan awan cumulus.

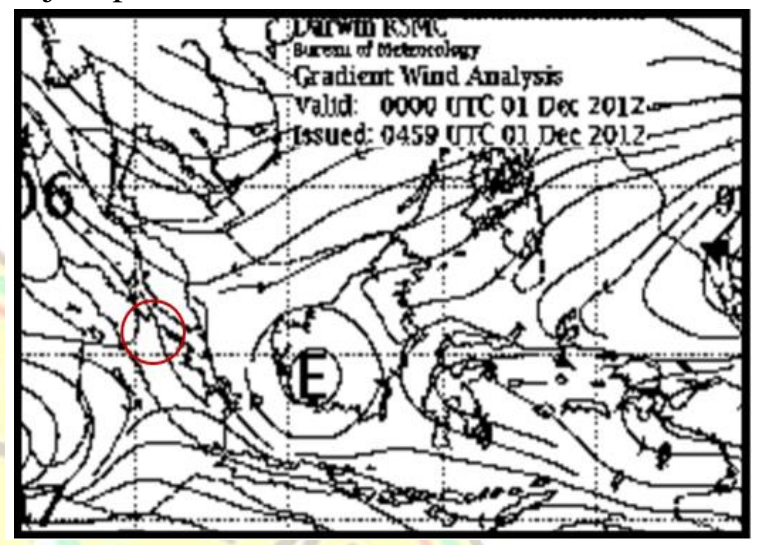

Gambar 11. Pola angin 3000 feet pada tanggal 1 Desember 2012

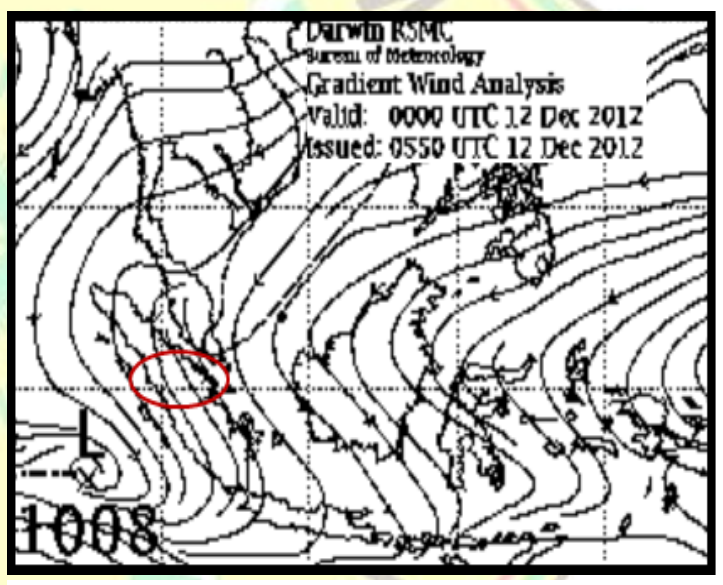

Gambar 11. Pola angin 3000 feet pada tanggal 12 Desember 2012

\section{KESIMPULAN DAN SARAN}

Berdasarkan dari hasil penelitian yang telah dilakukan dapat disimpulakan bahwa:

1. Kejadian awan $\mathrm{Cb}$ pada bulan Oktober Desember 2012 diawali dengan awan cumulus sekitar $79 \%$.

2. Perubahan suhu udara rata - rata pada bulan Oktober mengalami kenaikan suhu pada pukul 07.00 WIB hingga pukul 14.00 WIB suhu sekitar 7,5 0C dan tekanan udara mengalami penurunan sekitar $4,5 \mathrm{mb}$ pada pukul 10.00 WIB hingga pukul 16.00 WIB dengan persentase awan $\mathrm{Cb}$ terbanyak $12,5 \%$ pukul $15.00 \mathrm{WIB}$. 
3. Perubahan suhu udara rata - rata pada bulan November mengalami kenaikan suhu pada pukul 07.00 WIB hingga pukul 14.00 WIB suhu sekitar 7,6 0C dan tekanan udara mengalami penurunan sekitar $4,6 \mathrm{mb}$ pada pukul 10.00 WIB hingga pukul 16.00 WIB dengan persentase awan $\mathrm{Cb} 16,3 \%$ pukul 18.00 WIB.

4. Perubahan suhu udara rata - rata pada bulan Desember mengalami kenaikan suhu pada pukul 07.00 WIB hingga pukul 14.00 WIB suhu sekitar 7,1 0C dan tekanan udara mengalami penurunan sekitar $4,1 \mathrm{mb}$ pada pukul 10.00 WIB hingga pukul 16.00 WIB dengan persentase $11,9 \%$ pukul $15.00 \mathrm{WIB}$.

\section{DAFTAR PUSTAKA}

Sasmito Achmad.2011. Peringatan Dini dan Diagnosis munculnya Turbulensi Cuaca Cerah dan Dampaknya Pada Pesawat. Jurnal Meteorologi dan Geofisika Vol. 12 N0. 3 Hal. 291 - 302.

Tjasyono HK.,DEA , Bayong. 2006.

Meteorologi Indonesia 1 Karakterisrik dan sirkulasi atmosfer. Jakarta. Badan Meteorologi dan Geofisika.

Mayangwulan Dian.Wiratmo Joko dan Martuani Plato 2011. Potensi Kejadian Badai Guntur Berdasarkan Parameter Kelembapan, Labilitas Udara, dan mekanisme Pengangkatan. Jurnal Sains
Digrantara Vol. 8 No. 2 Hal. 139 - 156.

Bayong Tjasyono H. K. dan Harijono. 2006. Meteorologi Indonesia 2 Awan dan hujan monsun.Bandung.

Yunus S. Swarinoto dan Dian M.Wulan. 2005. Kondisi Angin dan Kelembaban Udara Musim Transisi. Jurnal Penelitian Meteorologi dan Geofisika. Vol. 6 No.3 Hal. 74 - 85 .

Wirjohamidjojo, S. 1995. Pokok-pokok Meteorologi Tropis. Jakarta: kursus Meteorologi Modifikasi Cuaca,Kerjasama Universitas Indonesia (UI).

Wirjohamidjojo, S. 2006.Meteorologi Praktik. Jakarta:Badan Meteorologi dan Geofisika.

Edison Kurniawan, Sukkendro,Titi Handayani, Analisi aktifitas guruh (thundestorm) terhadap stabilitas udara atmosphere, jurnal Meteorologi dan Geofisika. Jurnal vol: 5 No: 1 , jakarta, 2004.

Ahm,Murwadji. 2004.Cuaca Yang Signifikan Terhadap Penerbangan.

Irawadi,Rendy. 2008. Menentukan karakteristik awan cumulonimbus ( $\mathrm{Cb}$ ) di bandara polonia medan menggunakan analisa sounding. Skripsi

Juaeni Ina, Simulasi Numerik Konvensi Termal Dan Konvensi Awan Cumulus. Jurnal No.76 Bandung.

http://en.wikipedia.org/wiki/Thunderstorm. 